\title{
Familial cold urticaria
}

INSERM

\section{Source}

INSERM. (1999). Orphanet: an online rare disease and orphan drug data base. Familial cold urticaria. ORPHA:47045

Familial cold urticaria (FCAS) is the mildest form of cryopyrin-associated periodic syndrome (CAPS; see this term) and is characterized by recurrent episodes of urticarialike skin rash triggered by exposure to cold associated with low-grade fever, general malaise, eye redness and arthralgia/myalgia. 